\title{
Virulence and Resistance Characterization of Staphylococci- associated Urinary Tract Infection in Pregnant Women in Lagos, Nigeria
}

\section{Muinah A. Fowora}

Department of Molecular Biology and Biotechnology, Nigerian Institute of Medical Research. 6, Edmund Crescent, off Murtala Mohammed Way,

Yaba, Lagos, Nigeria

Faustina U. Onyeaghasiri

FOWM Biotechnology Limited, Lagos, Nigeria

\section{Ibilola Omolopo}

Adenike Aiyedogbon

Department of Molecular Biology and Biotechnology, Nigerian Institute of Medical Research. 6, Edmund Crescent, off Murtala Mohammed Way, Yaba, Lagos, Nigeria

\section{Idowu O. Edu-Muyideen}

Department of Microbiology, Nigerian Institute of Medical Research. 6, Edmund Crescent, off Murtala Mohammed Way, Yaba, Lagos, Nigeria

\section{Bamidele A. Iwalokun}

Department of Molecular Biology and Biotechnology, Nigerian Institute of Medical Research. 6, Edmund Crescent, off Murtala Mohammed Way, Yaba, Lagos, Nigeria

Doi:10.19044/esj.2021.v17n34p135

Submitted: 03 September 2021

Accepted: 13 September 2021

Published: 30 September 2021
Copyright 2021 Author(s)

Under Creative Commons BY-NC-ND 4.0 OPEN ACCESS

Cite As:

Fowora. M.A., Onyeaghasiri F.U., Omolopo I., Aiyedogbon A., Edu-Muyideen I.O. \& Iwalokun B.A. (2021). Virulence and Resistance Characterization of Staphylococciassociated Urinary Tract Infection in Pregnant Women in Lagos, Nigeria. European Scientific Journal, ESJ, 17(34), 135.

https://doi.org/10.19044/esj.2021.v17n34p135

\section{Abstract}

Background: Urinary Tract Infection (UTI) is the most prevalent bacterial infection in developing countries. UTI is sometimes asymptomatic. The occurrence of UTI in pregnancy can result in complications such as premature or low-birth-weight babies. Escherichia coli is the most common 
cause of UTI followed by Staphylococci species. However, E.coli associated UTI has been well studied while there is paucity of data on the virulence and resistance of Staphylococci-associated UTIs in women. This study aimed to characterize the virulence and resistance genes in Staphylococci species isolated from the urine of pregnant women.

Methods: This was a cross-sectional study involving pregnant women attending ante-natal clinic in Lagos State, Nigeria. Clean catch midstream urine specimens were collected from the women and cultured on appropriate agar. Bacteria were identified using both biochemical and molecular methods and evaluated for resistance to antibiotics. Polymerase chain reaction was used to detect the mecA and blaZ resistance genes and the PVL and TSST virulence genes.

Results: Staphylococci species were isolated from 21 (26.25\%) of the 80 urine samples of which 7 (29\%) were Staphylococcus aureus and 17 (71\%) coagulase-negative staphylococcus (CoNS). S. epidermidis and S. saprophyticus were the most commonly isolated CoNS. All the isolates tested were resistant to cotrimoxazole, cloxacillin, erythromycin, ampicillin, amoxicillin-clavulanate, and tetracycline. Both blaZ and the mecA genes were detected in the isolates that were phenotypically susceptible to methicillin and cefoxitin. There was an occurrence of the mecA, blaZ and PVL genes in S. saprophyticus in patients who were co-infected with S. aureus.

Conclusion: UTI caused by Staphylococci is common among pregnant women. There is a need to consider staphylococcal associated UTI screening in both symptomatic and asymptomatic cases of UTI in pregnant women.

Keywords: Urinary Tract Infection, Pregnant Women, Staphylococcus Species, Multi-Drug Resistance

\section{Introduction}

Urinary Tract Infection (UTI) is the invasion and subsequent propagation of microorganisms in the urinary tract and it is one of the most prevalent bacterial infections, especially in developing countries, with a high morbidity rate and financial costs (Foxman, 2014; Vasudevan, 2014). UTI is the most common hospital-acquired infection, accounting for up to $35 \%$ of nosocomial infections, and it is the second leading cause of bacteraemia in hospitalized patients (Agaba et al., 2017).

UTI is associated with several complications for both the fetus and the mother, including pyelonephritis, preterm birth, low birth weight, and increased perinatal mortality (Ghouri et al., 2019; Vasudevan, 2014). Some women who develop asymptomatic bacteriuria during pregnancy are more likely to have premature or low-birth-weight babies. 
The causative agents for UTI are many and differ from location to location and their patterns of susceptibility and resistance often vary. As with S. aureus, a high prevalence of coagulase-negative staphylococci (CoNS) causing UTI has also been reported (França et al., 2021; Hashmi et al., 2016; Higashide et al., 2008; Zia Sheikholeslami \& Hassanshahi, 2010). The Frequent and many reports about highly resistant staphylococcal-associated UTIs makes it imperative for this study on asymptomatic staphylococciassociated UTI in pregnant women taking into account the pathogenic roles, virulence and resistance genes. This study, therefore, aims to characterize the virulence and resistance genes in Staphylococci species isolated from the urine of pregnant women in Lagos, Nigeria.

\section{Materials and Methods \\ Study design and Area}

This was a cross-sectional study carried out in Lagos State, Nigeria. Samples were collected from pregnant women attending the ante-natal clinic of the Lagos University Teaching Hospital (LUTH) in Lagos State, Nigeria. Urine samples of pregnant women with or without symptoms of UTI, at any stage of pregnancy, and having significant bacteriuria were included in this study. Urine samples of pregnant women that had taken antibiotics within the last two weeks before sample collection were excluded from the study.

\section{Ethical Considerations}

Ethical approval to carry out this study was obtained from the Research Grants and Experimentation Ethics Committee, College of Medicine, University of Lagos. Participant's consent was obtained before sample collection started. Privacy, confidentiality and personal information of all patients were observed and protected.

\section{Specimen collection, Isolation and Phenotypic Identification of Staphylococcus Species}

A total of 80 clean-catch midstream urine specimens were collected into sterile containers. The samples were homogenized, $50 \mu \mathrm{l}$ of the urine was deposited on the surface of a microscope slide and allowed to dry at ambient temperature. The smears were fixed by passing through the flame of a Bunsen Burner and stained using the gram staining technique. Microscopic examination of the smears was initially done at 20x magnification to ensure that the samples were evenly distributed, and then at 100x magnification. A positive smear, indicative of significant bacteriuria according to the criteria of Washington et al. (1981), was defined as on that had $\geq 2$ per distributed uniformly per oil immersion field after the examination of at least 20 fields (Cardoso et al., 1998; Washington et al., 1981). 
The urine samples were cultured onto blood agar and mannitol salt agar (Oxoid, UK), then incubated aerobically for 24 hours at $37^{\circ} \mathrm{C}$. Colonies were examined after overnight incubation and sub-cultured to obtain a pure culture. Identification of bacteria was made according to colony morphology, Gram stain and biochemical tests. The isolates were initially identified by gram stain, susceptibility to $0.04 \mathrm{U}$ bacitracin (SigmaAldrich), catalase, and tube coagulase tests, and categorized as $S$. aureus and CoNS as described by Cunha et al., 2004. Then other biochemical tests were done to further identify the isolates. These include urease production, nitrate production, resistance to novobiocin, and sugar fermentation tests using the sugars sucrose, trehalose, xylose, a-lactose, fructose, maltose, and mannose (Cunha et al., 2004).

\section{Antibiotic susceptibility patterns}

Pure isolates were subjected to antimicrobial susceptibility testing using the modified disk diffusion Kirby-Bauer method as recommended by the Clinical and Laboratory Standard Institute (CLSI, 2020). A freshly prepared broth of 0.5 McFarland concentration of the isolate was cultured inoculated onto Mueller Hinton Agar after which antibiotic discs were applied.

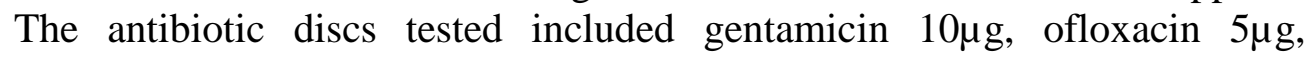

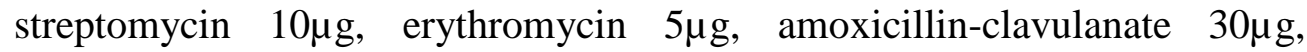
cloxacillin $5 \mu \mathrm{g}$, cotrimoxazole $25 \mu \mathrm{g}$, tetracycline $25 \mu \mathrm{g}$, imipenem $10 \mu \mathrm{g}$,

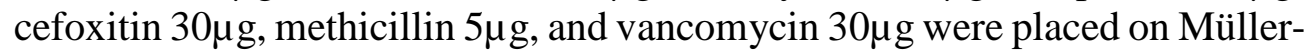
Hinton agar and incubated aerobically at $37^{\circ} \mathrm{C}$ for 24 hours (Oxoid, UK). The zones of inhibition were measured and interpreted as sensitive or resistant using the CLSI criteria.

\section{DNA extraction and Polymerase Chain reaction}

DNA was extracted using the boiling - centrifugation method according to Soumet et al., 1994. Polymerase chain reaction (PCR) was carried out to amplify the resistance and virulence gene loci. The 16s rRNA gene and the virulence genes were detected using a standard single PCR while the resistance genes and the nuc genes were detected using duplex PCR (mecA and nuc combination and blaZ and nuc combination). PCR was performed in a $20 \mu \mathrm{l}$ reaction mixture containing $1 \mathrm{X}$ Master mix (Solis Biodyne) (the master mix contained 1X PCR Buffer, $1.5 \mathrm{mM} \mathrm{MgCl}_{2}, 200 \mu \mathrm{M}$ of each deoxynucleoside triphosphates, and 2U Taq DNA Polymerase), 20pMol of each primer (BIOMERS, Germany), $2 \mu \mathrm{l}$ of the extracted DNA, and nucleasefree water was used to make up the reaction mixture volume.

Thermal cycling was conducted in a Peltier PTC 200 thermal cycling for an initial denaturation of $95^{\circ} \mathrm{C}$ for 5 minutes followed by 35 amplification cycles of 30 seconds at $95^{\circ} \mathrm{C}$; 45 seconds at the annealing temperature and 1 minute at $72^{\circ} \mathrm{C}$, followed by a final extension step of 10 minutes at $72^{\circ} \mathrm{C}$. The 
primer sequences and the annealing temperatures employed to detect the virulence and resistance genes are presented in Table 1.

The amplification product was separated by electrophoresis on a $1.5 \%$ agarose gel at $80 \mathrm{~V}$ for 1 hour 30 minutes. After electrophoresis, DNA bands were stained with ethidium bromide and visualized. 100bp DNA ladder (Solis Biodyne) was used as DNA molecular weight marker.

Table 1. Primer sequences, gene locus and Amplicon sizes

\begin{tabular}{|c|c|c|c|c|c|}
\hline Primer & $\begin{array}{c}\text { Primer sequence }\left(5^{\prime}-\right. \\
\left.3^{\prime}\right)\end{array}$ & Specific gene loci tested & $\begin{array}{l}\text { Annealing } \\
\text { Temperature } \\
\left({ }^{\circ} \mathrm{C}\right)\end{array}$ & $\begin{array}{l}\text { Product } \\
\text { size } \\
\text { (bp) }\end{array}$ & Reference \\
\hline $\begin{array}{l}16 S r R \\
N A-\mathrm{F}\end{array}$ & $\begin{array}{c}\text { 5' GTA GGT GGC } \\
\text { AAG CGT TAT CC 3' }\end{array}$ & \multirow{2}{*}{$\begin{array}{c}\text { 16S ribosomal } \\
\text { ribonucleic acid } \\
\text { (Staphylococcus genus- } \\
\text { specific) }\end{array}$} & \multirow[t]{2}{*}{55} & \multirow[t]{2}{*}{228} & \multirow[t]{2}{*}{$\begin{array}{l}\text { (Bakheet et } \\
\text { al., 2018) }\end{array}$} \\
\hline $\begin{array}{l}16 S r R \\
N A-\mathrm{R} \\
\end{array}$ & $\begin{array}{c}\text { 5' CGC ACA TCA } \\
\text { GCG TCA G 3' }\end{array}$ & & & & \\
\hline nuc-F & $\begin{array}{c}\text { 5'-GCG ATT GAT } \\
\text { GGT GAT ACG } \\
\text { GTT-3' }\end{array}$ & \multirow[t]{2}{*}{$\begin{array}{l}\text { Thermonuclease gene } \\
\text { (S. aureus specific) }\end{array}$} & \multirow[t]{2}{*}{55} & \multirow[t]{2}{*}{279} & \multirow[t]{2}{*}{$\begin{array}{l}\text { (Brakstad et } \\
\text { al., 1992) }\end{array}$} \\
\hline nuc- $\mathrm{R}$ & $\begin{array}{c}\text { 5' AGC CAA GCC } \\
\text { TTG ACG AAC TAA } \\
\text { AGC 3' }\end{array}$ & & & & \\
\hline mесA-F & $\begin{array}{c}\text { 5' GTG AAG ATA } \\
\text { TAC CAA GTG ATT } \\
\text { 3' }\end{array}$ & \multirow[t]{2}{*}{ mecA gene } & \multirow[t]{2}{*}{55} & \multirow[t]{2}{*}{147} & \multirow[t]{2}{*}{$\begin{array}{l}\text { (Zhang et } \\
\text { al., 2005) }\end{array}$} \\
\hline $\begin{array}{l}\text { mecA- } \\
\mathrm{R}\end{array}$ & $\begin{array}{c}\text { 5' ATG CGC TAT } \\
\text { AGA TTG AAA GGA } \\
\text { T 3' }\end{array}$ & & & & \\
\hline blaZ-F & $\begin{array}{c}\text { 5' AAG AGA TTT } \\
\text { GCC TAT GCT TC 3' }\end{array}$ & \multirow[t]{2}{*}{ blaZ gene } & \multirow[t]{2}{*}{52} & \multirow[t]{2}{*}{517} & \multirow[t]{2}{*}{$\begin{array}{l}\text { (Bakheet et } \\
\text { al., 2018) }\end{array}$} \\
\hline blaZ-R & $\begin{array}{c}\text { 5' GCT TGA CCA } \\
\text { CTT TTA TCA GC 3' }\end{array}$ & & & & \\
\hline $\begin{array}{l}\text { Luk- } \\
P V-1\end{array}$ & $\begin{array}{c}\text { 5' ATC ATT AGG } \\
\text { TAA AAT GTC TGG } \\
\text { ACA TGA TCC A 3' }\end{array}$ & \multirow[t]{2}{*}{$\begin{array}{l}\text { Panton Valentine } \\
\text { Leucocidin Toxin }\end{array}$} & \multirow[t]{2}{*}{55} & \multirow[t]{2}{*}{433} & \multirow[t]{2}{*}{$\begin{array}{l}\text { (Lina et al., } \\
\text { 1999) }\end{array}$} \\
\hline $\begin{array}{l}\text { Luk- } \\
P V-2\end{array}$ & $\begin{array}{c}\text { 5' GCA TCA AST } \\
\text { GTA TTG GAT AGC } \\
\text { AAA AGC 3' }\end{array}$ & & & & \\
\hline TSST-F & $\begin{array}{c}\text { 5' GCT TGC GAC } \\
\text { AAC TGC TAC AG } \\
\text { 3' }\end{array}$ & \multirow[t]{2}{*}{$\begin{array}{c}\text { Toxic shock syndrome } \\
\text { toxin-1 }\end{array}$} & \multirow[t]{2}{*}{50} & \multirow[t]{2}{*}{559} & \multirow[t]{2}{*}{$\begin{array}{c}\text { (Wang et al., } \\
\text { 2016) }\end{array}$} \\
\hline TSST-R & $\begin{array}{c}\text { 5' TGG ATT CGT } \\
\text { CAT TCA TTC TTA } \\
\text { T 3' }\end{array}$ & & & & \\
\hline
\end{tabular}

\section{Results}

\section{Isolation and identification of Staphylococcus species}

Staphylococcus species were isolated from 21 (26.25\%) of the 80 urine samples collected from pregnant women. Of the 21 women, 18 had a single 
infection while 3 were infected with a co-infection of Staphylococcus aureus and Staphylococcus saprophyticus, making a total of 24 Staphylococcus species isolated. These included S. aureus 7 (29\%) and CoNS 17 (71\%). The CoNS were further identified as Staphylococcus epidermidis $41.1 \%$, Staphylococcus saprophyticus $35.3 \%$, Staphylococcus haemolyticus $11.80 \%$, and other staphylococci $11.8 \%$.

\section{Molecular Identification of the Isolates}

All the 24 isolates showed amplification and were, therefore, confirmed as Staphylococcus species using the Staphylococcus genus-specific 16SrRNA (Figure 1). The nuc gene was amplified to further identify the $S$. aureus isolates. Only the 7 isolates presumptively identified as $S$. aureus showed amplification for the nuc gene (Figure 2).

Figure 1. PCR detection of the 16SrRNA (228 bp) gene of Staphylococcus species

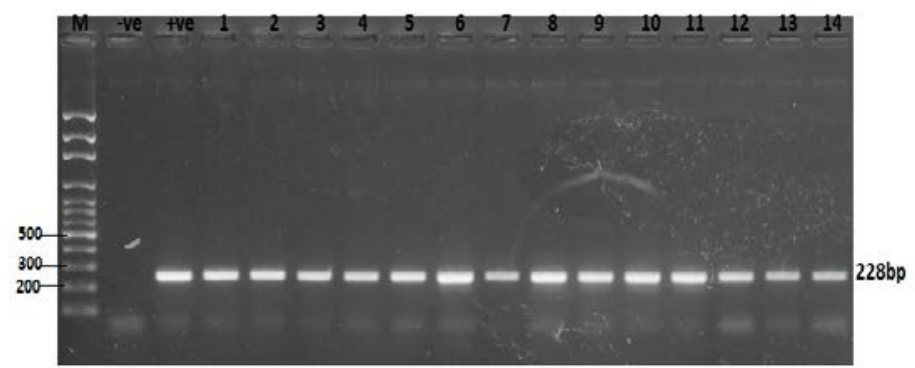

Key: $\mathrm{M}=100 \mathrm{bp}$ DNA Ladder (Solis Biodyne); -ve = negative control; +ve = positive control (NCTC 12493); Lanes 1-14 = Staphylococcal isolates

Figure 2. Multiplex-PCR assay for the detection of mecA and nuc gene

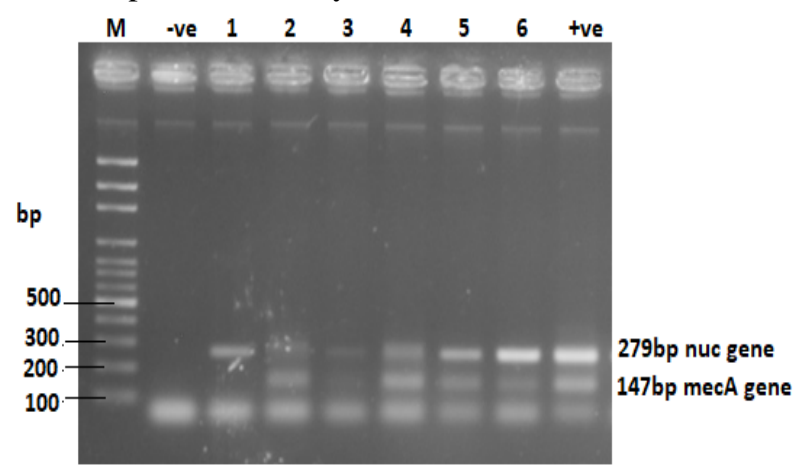

Key: $\mathrm{M}=100 \mathrm{bp}$ DNA Ladder (Solis Biodyne); -ve = negative control; +ve = positive control (NCTC 12493); Lane 1 = mecA negative S. aureus sample; Lanes 2 - 6 = mecA positive $S$. aureus samples

\section{Antimicrobial Susceptibility Test Result}

The result of the antimicrobial susceptibility testing is summarized in Table 2 with all the isolates being multiple resistant to four or more antibiotics. 
All the isolates of both S. aureus and CoNS were resistant to cotrimoxazole, cloxacillin, erythromycin, ampicillin, amoxicillin-clavulanate, and tetracycline. All the $S$. aureus isolated were susceptible to vancomycin and imipenem, while cefoxitin, methicillin, vancomycin, and imipenem were the most effective antibiotics in the CoNS with all the CoNS isolates being susceptible to these antibiotics. About four different patterns of resistance were seen in the $S$. aureus isolates with all patterns containing the cotrimoxazole-cloxacillin-erythromycin-ampicillin-Amoxicillin/clavulanatetetracyclin-chloramphenicol resistant pattern (Table 3). Seven different patterns of resistance were seen in the CoNS isolates with the cotrimoxazolecloxacillin-erythromycin-ampicillin-amoxicillin/clavulanate-tetracyclin resistance seen in all the seven different patterns (Table 3).

Table 2. Distribution of Antimicrobial Resistance of Staphylococcus aureus and CoagulaseNegative Staphylococci from Urinary Tract Infections

\begin{tabular}{|c|c|c|c|c|}
\hline \multirow{2}{*}{ Antibiotics } & \multicolumn{3}{|c|}{ Staphylococcus aureus (n =7) } & \multicolumn{2}{c|}{$\begin{array}{c}\text { Coagulase Negative Staph (n } \\
=17)\end{array}$} \\
\cline { 2 - 5 } & $\begin{array}{c}\text { Sensitive } \\
(\%)\end{array}$ & Resistant (\%) & $\begin{array}{c}\text { Sensitive } \\
(\%)\end{array}$ & Resistant (\%) \\
\hline Cotrimoxazole & 0 & 100 & 0 & 100 \\
\hline Cloxacillin & 0 & 100 & 0 & 100 \\
\hline Erythromycin & 0 & 100 & 0 & 100 \\
\hline Ampicillin & 0 & 100 & 0 & 100 \\
\hline Gentamicin & 28.57 & 71.43 & 17.65 & 82.35 \\
\hline Amoxicillin- & 0 & 100 & 0 & 100 \\
\hline Clavulanate & & & & 64.71 \\
\hline Streptomycin & 28.57 & 71.43 & 35.29 & 100 \\
\hline Tetracycline & 0 & 100 & 0 & 76.48 \\
\hline Chloramphenicol & 0 & 100 & 23.52 & 35.29 \\
\hline Ofloxacin & 57.1 & 42.9 & 64.71 & 0 \\
\hline Cefoxitin & 85.7 & 14.3 & 100 & 0 \\
\hline Methicillin & 85.7 & 14.3 & 100 & 0 \\
\hline Vancomycin & 100 & 0 & 100 & 0 \\
\hline Imipenem & 100 & 0 & 100 & \\
\hline
\end{tabular}

Table 3. Phenotypic Antimicrobial Resistance Patterns of Staphylococcus aureus and CoNS from Urinary Tract Infections

\begin{tabular}{|c|c|c|}
\hline \multicolumn{2}{|c|}{ Staphylococcus aureus (n = 7) } \\
\hline Resistance phenotypes & $\begin{array}{c}\text { Number } \\
\text { of strains }\end{array}$ & $\begin{array}{c}\text { Number of } \\
\text { antibiotic } \\
\text { classes }\end{array}$ \\
\hline COT, CXC, ERY, AMP, AMC, TET, CHL, GEN & 2 & 6 \\
\hline COT, CXC, ERY, AMP, AMC, TET, CHL, STR & 2 & 6 \\
\hline COT, CXC, ERY, AMP, AMC, TET, CHL, GEN, STR, OFL & 2 & 7 \\
\hline COT, CXC, ERY, AMP, AMC, TET, CHL, GEN, STR, \\
OFL, CFX, MET
\end{tabular}




\begin{tabular}{|c|c|c|}
\hline Resistance phenotypes & $\begin{array}{c}\text { Number } \\
\text { of strains }\end{array}$ & $\begin{array}{c}\text { Number of } \\
\text { antibiotic } \\
\text { classes }\end{array}$ \\
\hline COT, CXC, ERY, AMP, AMC, TET, & 2 & 4 \\
\hline COT, CXC, ERY, AMP, AMC, TET, GEN, STR & 1 & 5 \\
\hline COT, CXC, ERY, AMP, AMC, TET, STR, OFL & 1 & 5 \\
\hline COT, CXC, ERY, AMP, AMC, TET, CHL, GEN, & 1 & 6 \\
\hline COT, CXC, ERY, AMP, AMC, TET, CHL, GEN, STR & 7 & 6 \\
\hline COT, CXC, ERY, AMP, AMC, TET, CHL, GEN, OFL & 3 & 7 \\
\hline COT, CXC, ERY, AMP, AMC, TET, CHL, GEN, STR, OFL & 2 & 7 \\
\hline
\end{tabular}

Key: Cot = Cotrimoxazole,; CXC = Cloxacillin; ERY = Erythromycin; AMP = Ampicillin; GEN = Gentamicin; AMC = Amoxicillin-Claulanate; STR = Streptomycin; TET = Tetracycline; CHL = Chloramphenicol; OFL = Ofloxacin; CFX = Cefoxitin; MET = Methicillin

\section{Detection of the resistant genes mecA and blaz}

mecA and blaZ gene detection was carried out on all the isolates irrespective of their phenotypic resistance to penicillin ( $\beta$-lactam) antibiotics. The mecA and blaZ amplification products are as presented in Figure 2 and Figure 3. The mecA gene was detected in $57.1 \%$ (4/7) of the $S$. aureus isolates, even in isolates that were phenotypically susceptible to methicillin and Cefoxitin. Similarly, the blaZ gene was also detected in $57.1 \%(4 / 7)$ of the $S$. aureus isolates. The mecA gene was also detected in $41.2 \%(7 / 17)$ and the blaZ $52.9 \%(9 / 14)$ of the CoNS isolates. The resistant gene patterns of the isolates are presented in Table 4.

Figure 3. Multiplex-PCR assay for the detection of blaZ and nuc gene

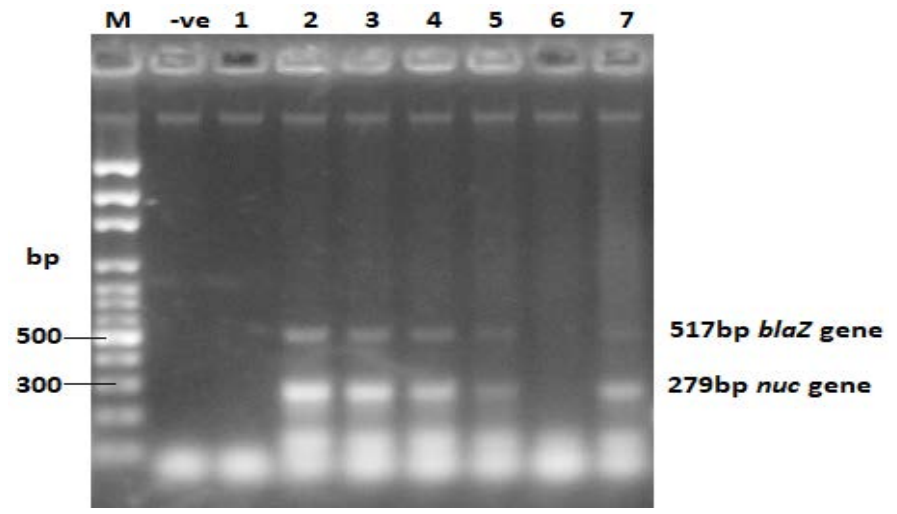

Key: $\mathrm{M}=100 \mathrm{bp}$ DNA Ladder (Solis Biodyne); -ve = negative control; Lane 1 and Lane 6= blaZ negative CoNS sample; Lanes $2-5$ = blaZ positive $\mathrm{S}$. aureus samples; Lane 7 = positive control (NCTC 12493)

Table 4. Resistance and Virulence Gene Patterns of Staphylococcus aureus and CoNS from Urinary Tract Infections

\begin{tabular}{|c|c|c|}
\hline Resistance/Virulence Genes & SA $(\mathrm{n}=7)$ & CoNS $(\mathrm{n}=17)$ \\
\hline mecA alone & 0 & 0 \\
\hline
\end{tabular}




\begin{tabular}{|c|c|c|}
\hline blaZ alone & 0 & $2(11.8 \%)$ \\
\hline mecA, blaZ & $2(28.6 \%)$ & $6(35.3 \%)$ \\
\hline mecA, blaZ, TSST & $2(28.6 \%)$ & $1(5.9 \%)$ \\
\hline
\end{tabular}

\section{PVL and TSST Virulent Gene Detection}

None of the samples showed amplification for the PVL gene. However, 28.6\% (2/7) and 5.9\% (1/17) of the S. aureus and CoNS isolates respectively showed amplification for the TSST-1 (Figure 4) gene. The virulence and resistance gene patterns of the isolates are presented in Table 4.

Figure 4. Multiplex-PCR assay for the detection of blaZ and nuc gene

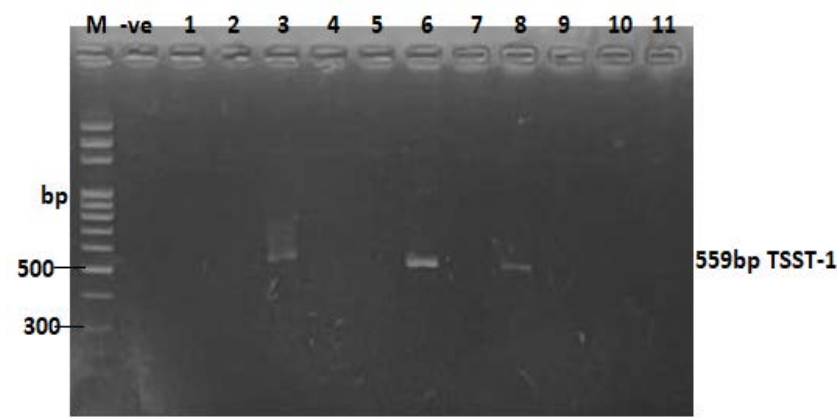

Key: $\mathrm{M}=100 \mathrm{bp}$ DNA Ladder (Solis Biodyne); - ve = negative control; Lane $1-7=S$. aureus strains and Lane $8-11=$ CNS strains

\section{Discussion}

UTIs typically manifest as asymptomatic and symptomatic bacteriuria with a prevalence of $15 \%$ in pregnant women. Though the treatment of asymptomatic bacteriuria in UTI may not be necessary for healthy adults and non-pregnant women, it is, however, important to screen and treat asymptomatic bacteriuria in pregnant women (Alemu et al., 2012). This is due to complications such as pyelonephritis, preterm birth, low birth weight, and increased perinatal mortality, which UTI can cause in pregnant women. Hence, the treatment of UTI is vital in preventing maternal and neonatal complications (Alemu et al., 2012; Kalinderi et al., 2018).

The majority of pregnant women with bacteriuria were asymptomatic in this study. The prevalence of staphylococci-associated UTI was $26.25 \%$, with the prevalence of $S$. aureus and CoNS being $8.8 \%$ and $21.25 \%$ of the overall total samples collected respectively, and $29 \%$ and $71 \%$ of staphylococcal cultures respectively. Though most studies originating from Nigeria on the prevalence of UTI in pregnant women have reported lower rates of CoNS in UTI associated with pregnant women (Okonko et al., 2010; Oladeinde et al., 2015; Simon-Oke et al., 2019), this study reports a higher prevalence of CoNS in staphylococcal associated UTI in pregnant women. 
Staphylococcus epidermidis and Staphylococcus saprophyticus were the most predominant CoNS isolated from UTIs in pregnant women as seen in this study. This corroborates the study by Hashmi et al. (2016) which also reported S. saprophyticus and S. epidermidis as the most common CoNS causing staphylococcal associated UTI in women. S. saprophyticus has been reported as one of the most common causes of community-acquired urinary tract infections, second only to Escherichia coli, and causing about $42 \%$ of infections in sexually active women (Hur et al., 2016). The presence of $S$. epidermidis and S. saprophyticus in UTIs in pregnant women should not be overlooked. S. epidermidis, though considered nosocomial and benign, have been implicated in causing obstetrical complications and infections in neonates (Beksac et al., 2019; Upadhyayula et al., 2012). S. saprophyticus has also been implicated as a common culprit in polymicrobial UTIs which are typically seen in the immunocompromised. In this study, subjects that had coinfection of multiple staphylococcal species infections had $S$. saprophyticus as one of the co-infection. This further adds credence to the association of $S$. saprophyticus in polymicrobial UTIs.

All the staphylococcal isolates seen in this study showed resistance to cotrimoxazole, cloxacillin, erythromycin, ampicillin, amoxicillin-clavulanate, and tetracycline, with the most effective antibiotics being vancomycin and imipenem. Apart from being susceptible to cloxacillin and imipenem, the CoNS were also susceptible to vancomycin and imipenem. Hashmi et al. (2016) also reported a 100\% susceptibility to Vancomycin in CoNS. In this study, resistance was recorded for almost all the classes of antibiotics apart from the glycopeptides and carbapenems. Resistance of Staphylococcus species to penicillin and the $\beta$-lactams is a worldwide problem and the subsequent high levels of resistance to tetracycline, aminoglycosides and to some extent macrolides as seen in this study makes it increasingly difficult for clinicians to make safe antibiotic choices for the treatment of UTIs in pregnancy (Alemu et al., 2012; Mohammad et al., 2002). Easy access and the indiscriminate use of antibiotics such as ampicillin, tetracycline, and cotrimoxazole in Nigeria may influence the increasing resistance seen in these organisms.

Methicillin resistance and the detection of the mecA gene in CoNS isolated from UTIs, specifically from $S$. Saprophyticus have been reported (Hashmi et al., 2016). The detection of mecA and/or blaZ even in isolates that were phenotypically susceptible to methicillin and cefoxitin may imply a further increase in resistance to these antibiotics in the future. All the mecA positive isolates were also blaZ positive. This can be attributed to the fact that methicillin resistance can also occur as a result of the inactivation of this antibiotic due to an increase in the production of beta-lactamase that is coded by the blaZ gene (Soares et al., 2012). Though there are few reports of mecA- 
mediated resistance in CoNS, this study detected both mecA and blaZ genes in S. saprophyticus and even in S. epidermidis. Other studies have also reported the presence of the mecA-mediated resistance in $S$. saprophyticus and $S$. epidermidis (Hanssen \& Ericson Sollid, 2007; Hashmi et al., 2016). Both the mecA and blaZ genes were detected in all the S. saprophyticus found in coinfection with $S$. aureus. It is, therefore, possible that the $S$. saprophyticus may have acquired their resistance through horizontal gene transfer from MRSA. This could also imply that $S$. saprophyticus is not only a commensal bacteria but also infectious.

The toxic shock syndrome toxin, which is encoded by the tst gene, upsets the cells of the immune system and stimulates the release of cytokines and other non-specific $\mathrm{T}$ cell proliferation resulting in toxic shock syndrome which is potentially fatal in humans (Hakimi Alni et al., 2018). In this study, the tst gene was detected in two $S$. aureus strains of which one of them was co-infected with $S$. Saprophyticus. This again supports the possibility of horizontal gene transfer from MRSA.

\section{Conclusions}

This study shows that both $S$. aureus and CoNS with a prevalence of (26.25\%) are uropathogens whose treatment should be considered in pregnancy. The high level of resistance seen in these study means that multidrug resistance is common in staphylococcal isolates from UTIs, and there is, therefore, a need to consider staphylococcal associated UTI screening in both symptomatic and asymptomatic cases of UTI in pregnant women to alleviate the consequences of asymptomatic UTI and multi-drug resistant staphylococcal infection in pregnancy.

\section{References:}

1. Agaba, P., Tumukunde, J., Tindimwebwa, J. V. B., \& Kwizera, A. (2017). Nosocomial bacterial infections and their antimicrobial susceptibility patterns among patients in Ugandan intensive care units: A cross sectional study. BMC Research Notes, 10(1), 1-12. https://doi.org/10.1186/s13104-017-2695-5

2. Alemu, A., Moges, F., Shiferaw, Y., Tafess, K., Kassu, A., Anagaw, B., \& Agegn, A. (2012). Bacterial profile and drug susceptibility pattern of urinary tract infection in pregnant women at University of Gondar Teaching Hospital, Northwest Ethiopia. BMC Research Notes, 5. https://doi.org/10.1186/1756-0500-5-197

3. Bakheet, A., Amen, O., Habaty, S., \& Darwish, S. (2018). Prevalence of Staphylococcus aureus In Broiler Chickens with Special Reference to Beta-Lactam Resistance Genes in the Isolated Strains. Alexandria Journal of Veterinary Sciences, 59(1), 25. 
https://doi.org/10.5455/ajvs.297627

4. Beksac, A. T., Orgul, G., Tanacan, A., Uckan, H., Sancak, B., Portakal, O., \& Beksac, M. S. (2019). Uropathogens and Gestational Outcomes of Urinary Tract Infections in Pregnancies that Necessitate Hospitalization. Current Urology, 13(2), 70-73.

https://doi.org/10.1159/000499290

5. Brakstad, O. D. D. G., Aasbakk, K., \& Maeland, J. A. (1992). Detection of Staphylococcus aureus_nuc pcr und primer. Journal of Clinical Microbiology, 30(7), 1654-1660.

http://www.ncbi.nlm.nih.gov/pubmed/1629319\%0Ahttp://www.pub medcentral.nih.gov/articlerender.fcgi?artid=PMC265359

6. Cardoso, C. L., Muraro, C. B., Siqueira, V. L. D., \& Guilhermetti, M. (1998). Simplified technique for detection of significant bacteriuria by microscopic examination of urine. Journal of Clinical Microbiology, 36(3), 820-823. https://doi.org/10.1128/jcm.36.3.820-823.1998

7. Clinical and Laboratory Standards Institute. (2020). Clinical and Laboratory Standards Institute (CLSI). Performance Standards for Antimicrobial Susceptibility Testing. 30th ed. CLSI Supplement M100.

8. Cunha, M. D. L. R. S., Sinzato, Y. K., \& Silveira, L. V. A. (2004). Comparison of methods for the identification of coagulase-negative staphylococci. Memorias Do Instituto Oswaldo Cruz, 99(8), 855-860. https://doi.org/10.1590/S0074-02762004000800012

9. Foxman, B. (2014). Urinary tract infection syndromes. Occurrence, recurrence, bacteriology, risk factors, and disease burden. Infectious Disease Clinics of North America, 28(1), 1-13. https://doi.org/10.1016/j.idc.2013.09.003

10. França, A., Gaio, V., Lopes, N., \& Melo, D. R. (2021). Virulence Factors in Coagulase-Negative Staphylococci.

11. Ghouri, F., Hollywood, A., \& Ryan, K. (2019). Urinary tract infections and antibiotic use in pregnancy-qualitative analysis of online forum content. BMC Pregnancy and Childbirth, 19(1), 1-8. https://doi.org/10.1186/s12884-019-2451-z

12. Hakimi Alni, R., Mohammadzadeh, A., Mahmoodi, P., \& Alikhani, M. Y. (2018). Detection of Toxic Shock Syndrome Toxin (tsst) Gene Among Staphylococcus aureus Isolated from Patients and Healthy Carriers . Avicenna Journal of Clinical Microbiology and Infection, 5(1), 14249-14249. https://doi.org/10.5812/ajcmi.14249

13. Hanssen, A. M., \& Ericson Sollid, J. U. (2007). Multiple staphylococcal cassette chromosomes and allelic variants of cassette chromosome recombinases in Staphylococcus aureus and coagulasenegative staphylococci from Norway. Antimicrobial Agents and 
Chemotherapy, 51(5), 1671-1677. https://doi.org/10.1128/AAC.00978-06

14. Hashmi, A., Abdullah, F. E., Abdullah, N. E., \& Kazmi, S. U. (2016). Species identification and antibiotic susceptibilities of coagulase negative staphylococci isolated from urinary tract infection specimens. Journal of the College of Physicians and Surgeons Pakistan, 26(7), 581-584. https://doi.org/2375

15. Higashide, M., Kuroda, M., Omura, C. T. N., Kumano, M., Ohkawa, S., Ichimura, S., \& Ohta, T. (2008). Methicillin-resistant Staphylococcus saprophyticus isolates carrying Staphylococcal cassette chromosome mec have emerged in urogenital tract infections. Antimicrobial Agents and Chemotherapy, 52(6), 2061-2068. https://doi.org/10.1128/AAC.01150-07

16. Hur, J., Lee, A., Hong, J., Jo, W. Y., Cho, O. H., Kim, S., \& Bae, I. G. (2016). Staphylococcus saprophyticus bacteremia originating from urinary tract infections: A case report and literature review. Infection and Chemotherapy, 48(2), 136-139.

https://doi.org/10.3947/ic.2016.48.2.136

17. Kalinderi, K., Delkos, D., Kalinderis, M., Athanasiadis, A., \& Kalogiannidis, I. (2018). Urinary tract infection during pregnancy: current concepts on a common multifaceted problem. Journal of Obstetrics and Gynaecology, 38(4), 448-453.

https://doi.org/10.1080/01443615.2017.1370579

18. Lina, G., Piémont, Y., Godail-Gamot, F., Bes, M., Peter, M. O., Gauduchon, V., Vandenesch, F., \& Etienne, J. (1999). Involvement of Panton-Valentine leukocidin-producing Staphylococcus aureus in primary skin infections and pneumonia. Clinical Infectious Diseases, 29(5), 1128-1132. https://doi.org/10.1086/313461

19. Mohammad, M., Mahdy, Z. A., Omar, J., Maan, N., \& Jamil, M. A. (2002). Laboratory aspects of asymptomatic bacteriuria in pregnancy. Southeast Asian Journal of Tropical Medicine and Public Health, 33(3), 575-580.

20. Okonko, I. O., Ijandipe, L. A., Ilusanya, A. O., Donbraye-Emmanuel, O. B., Ejembi, J., Udeze, A. O., Egun, O. C., Fowotade, A., \& Nkang, A. O. (2010). Detection of urinary tract infection (UTI) among pregnant women in Oluyoro Catholic Hospital, Ibadan, South-Western Nigeria. Malaysian Journal of Microbiology, 6(1), 16-24.

21. Oladeinde, B. H., Omoregie, R., \& Oladeinde, O. B. (2015). Asymptomatic urinary tract infection among pregnant women receiving ante-natal care in a traditional birth home in Benin City, Nigeria. Ethiopian Journal of Health Sciences, 25(1), 3-8.

https://doi.org/10.4314/ejhs.v25i1.2 
22. Simon-Oke, I. A., Odeyemi, O., \& Afolabi, O. J. (2019). Incidence of urinary tract infections and antimicrobial susceptibility pattern among pregnant women in Akure, Nigeria. Scientific African, 6, e00151. https://doi.org/10.1016/j.sciaf.2019.e00151

23. Soares, L. C., Pereira, I. A., Pribul, B. R., Oliva, M. S., Coelho, S. M. O., \& Souza, M. M. S. (2012). Antimicrobial resistance and detection of mecA and blaZ genes in coagulase-negative Staphylococcus isolated from bovine mastitis. Pesquisa Veterinaria Brasileira, 32(8), 692-696. https://doi.org/10.1590/S0100-736X2012000800002

24. Soumet, C., Ermel, G., Fach, P., \& Colin, P. (1994). Evaluation of different DNA extraction procedures for the detection of Salmonella from chicken products by polymerase chain reaction. Letters in Applied Microbiology, 19(5), 294-298. https://doi.org/10.1111/j.1472-765X.1994.tb00458.x

25. Upadhyayula, S., Kambalapalli, M., \& Asmar, B. I. (2012). Staphylococcus epidermidis Urinary Tract Infection in an Infant . Case Reports in Infectious Diseases, 2012, 1-2. https://doi.org/10.1155/2012/983153

26. Vasudevan, R. (2014). Urinary Tract Infection: An Overview of the Infection and the Associated Risk Factors. Journal of Microbiology \& Experimentation, 1(2), 42-54.

https://doi.org/10.15406/jmen.2014.01.00008

27. Wang, D., Zhang, L., Zhou, X., He, Y., Yong, C., Shen, M., Szenci, O., \& Han, B. (2016). Antimicrobial susceptibility, virulence genes, and randomly amplified polymorphic DNA analysis of Staphylococcus aureus recovered from bovine mastitis in Ningxia, China. Journal of Dairy Science, 99(12), 9560-9569. https://doi.org/10.3168/jds.2016-11625

28. Washington, J. A., White, C. M., Laganiere, R.N., M., \& Smith, L. H. (1981). Detection of Significant Bacteriuria by Microscopic Examination of Urine. Laboratory Medicine, 12(5), 294-296. https://doi.org/10.1093/labmed/12.5.294

29. Zhang, K., McClure, J. A., Elsayed, S., Louie, T., \& Conly, J. M. (2005). Novel multiplex PCR assay for characterization and concomitant subtyping of staphylococcal cassette chromosome mec types I to V in methicillin-resistant Staphylococcus aureus. Journal of Clinical Microbiology, 43(10), 5026-5033. https://doi.org/10.1128/JCM.43.10.5026-5033.2005

30. Zia Sheikholeslami, N., \& Hassanshahi, G. (2010). The frequency of coagulase negative staphylococci urinary infections with antimicrobial resistance pattern in rafsanjan. Pakistan Journal of Medical Sciences, 26(1), 107-110. 